\title{
ANALISIS PENGARUH PELAYANAN PUBLIK DAN E-SERVICE QUALITY TERHADAP KEPUASAN MASYARAKAT DI LINGKUNGAN PEMERINTAHAN KOTA JAMBI
}

\author{
Hendriyaldi $^{1}$, Musnaini ${ }^{2}$ \\ ${ }^{1,2)}$ Dosen Universitas Jambi \\ hendriyaldi@unja.ac.id ${ }^{1)}$, musnaini@unja.ac.id ${ }^{2)}$
}

\begin{abstract}
Abstrak
Di era digitalisasi, setiap instansi pemerintah diharapkan mampu menyelesaikan permasalahan masyarakat dengan cepat dan berbasis teknologi dalam menghadapi era revolusi industri 4.0. Pemerintah tidak hanya dituntut untuk menyediakan layanan sistem konvensional, tetapi juga menyediakan layanan berbasis teknologi atau elektronik. Kemudian terciptanya kolaborasi antara karyawan dan teknologi sekaligus melayani masyarakat. Tujuan penelitian adalah untuk melihat pengaruh pelayanan publik terhadap kepuasan masyarakat dan pengaruh e-service quality terhadap kepuasan masyarakat di Kota Jambi. Penelitian ini menggunakan penelitian kuantitatif deskriptif. Data menggunakan metode kuesioner yang diberikan kepada responden yang menyatakan pernyataan terkait objek penelitian yaitu pelayanan publik, e-service quality dan kepuasan masyarakat. Dalam penelitian pengambilan sampel ini menggunakan teknik purposive sampling. Jumlah sampel sebanyak 60 orang. Pengukuran menggunakan variabel skala likert. Teknik pengujian instrumen validitas dan reliabilitas. Hasil penelitian menunjukkan bahwa ada pengaruh positif signifikan pelayanan publik terhadap kepuasan masyarakat, ada pengaruh positif signifikan e-services quality terhadap kepuasan masyarakat, dan ada pengaruh positif signifikan kualitas pelayanan publik dan e-service quality secara bersama-sama terhadap kepuasaan masyarakat di Kota Jambi.
\end{abstract}

Kata Kunci: Pelayanan Publik, E-Service Quality, Kepuasan Masyarakat

\begin{abstract}
In the era of digitalization, every government agency is expected to be able to solve community problems quickly and be technology-based in facing the era of the industrial revolution 4.0. The government is not only required to provide conventional system services, but also to provide technology-based or electronic services. Then the creation of collaboration between employees and technology while serving the community. This study aims to determine the influence of public services on community satisfaction and the influence of e-service quality on community satisfaction in the Jambi City. This study uses descriptive quantitative research. The data used a questionnaire method given to respondents who stated statements related to the object of research, namely public services, electronic service quality and community satisfaction. In this sampling research using purposive sampling technique.. The number of samples were 60 people. Measurement using a Likert scale variable. The technique of testing the instrument for validity and reliability. The results showed that there was a significant positive effect of public services on community satisfaction, there was a significant positive on the eservices quality on community satisfaction, and there was a significant positive of public services and e-services quality on community satisfaction together in Jambi City
\end{abstract}

Keywords: Public Service, E-Service Quality, Community Satisfaction 


\section{PENDAHULUAN}

Pada era digitalisasi perkembangan teknologi semakin canggih. Berbagai inovasi yang bermunculan disetiap instansi pemerintahan sebagai alat pendukung tata kelola pemerintahan sehingga tujuan yang diharapkan tercapai dengan baik. Kualitas pelayanan publik yang diberikan kepada masyarakat merupakan salah satu terwujudnya tata kelola good governance (pemerintahan yang baik). Di era digitalisasi, setiap lembaga pemerintah diharapkan agar dapat mengatasi permasalah masyarakat dengan cepat serta berbasis teknologi dalam menghadapi era revolusi industri 4.0. Menurut (Schwab, 2017) Revolusi 4.0 terdapat 3 bagian: secara fisik, biologis, dan digital. Pada secara fisik, terdapat 4 manifestasi, yakni kendaraan otomatis, $3 D$ printing, dan robotik, serta material-material yang baru. Selain itu, secara biologis yakni bagaimana perkembangan dan perubahan suatau teknologi yg dapat menciptakan hal-hal sebelumnya hanya bisa saksikan di dunia perfilman, misal rekayasa genetik dan bioprinting. Selanjutanya yang ketiga di secara digital, adanya kehadiran Internet of Things (IoT) membantu adanya revolusi industri 4.0.

Pada prinsipnya revolusi industri 4.0 merupakan penggabungan mesin, alur kerja, dan sistem, dengan menerapkan jaringan cerdas di sepanjang rantai dan proses produksi untuk mengendalikan satu sama lain secara mandiri (Lifter dan Tschiener, 2013). Sehingga dapat dikatakan bahwa pada saat ini berbagai fasilitas sudah terintegrasi dengan teknologi dan internet. Selain itu hampir semua aktivitas yang dilakukan masyarakat sudah terintegrasi dengan internet, dikutip dari tekno.kompas.com bahw populasi penduduk Indonesia sebanyak 270 juta jiwa, sekitar 64,8\% atau sebanyak 171,17 juta jiwa sudah terhubung dengan internet. Sehingga pemerintah yang seyogyanya sebagai pelayanan publik diharapkan mampu beradaptasi dalam menghadapi perubahan perilaku masyarakat.

Dengan mengikuti perkembangan zaman, untuk melayani publik, pemerintah tidak hanya menyediakan pelayanan sistem konvensional, melainkan juga menyediakan pelayanan berbasis teknolgi atau elektronik. Oleh karena itu, diharapkan pelayanan yang digunakan pemerintah dapat menggabungkan pekerjaan pegawai dengan sistem layanan berbasis teknologi atau elektronik seperti menyediakan sistem aplikasi yang dapat memberikan informasi kepada masyarakat dengan mudah, cepat dan tepat. Sesuai pendapat Baur dan Wee dalam (Hendriyaldi, 2019) menyatakan bahwa salah satu dalam aplikasi revolusi industri 4.0 pada labor, terciptanya kolaborasi robot atau teknologi dengan manusia. Berikut ada beberapa aplikasi layanan publik berbasis online dalam mengatasi permsalahan yang ada di masalah. Seperti pada gambar-gambar dibwah ini:
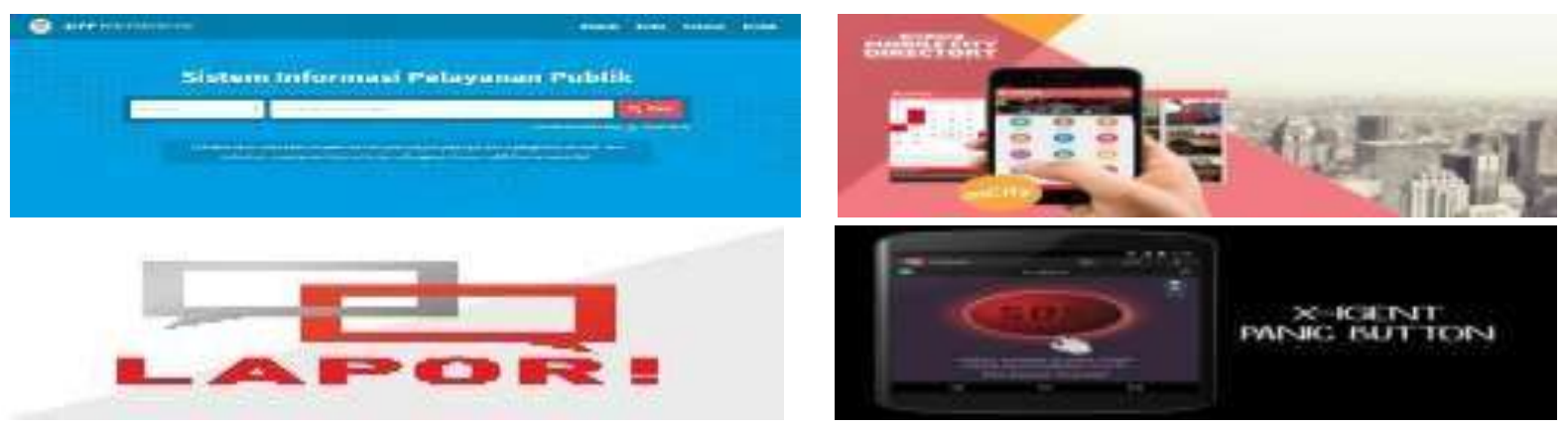

Gambar 1. Aplilasi Smart City

Dari berbagai aplikasi tersebut maka diharapan agar dapat membantu lembaga pemerintahan lebih infomatif dan dapat menjadi problem-solving agent bagi masyarakat sehingga permasalah yang dihadapi oleh masyarakat dapat teratasi dengan cepat dan lebih 
efisien. Sehingga pelayanan publik dapat dilaksanakan dengan baik.

Pelayanan publik merupakan sebagai pemberian layananan kepada masyarakat mempunyai kepentingan pada instansi yang sesuai aturan dan tata cara yang sudah ditetapkan. Sebagaimana telah diketahui bahwa pemerintahan pada hakekatnya adalah pelayanan kepada masyarakat. Karenanya menurut (Irsan, 2012) bahwa birokrasi publik diharuskan atau berkewajiban serta bertanggung jawab untuk memberikan pelayanan yang baik secara profesional. Kemudian pendapat (Moenir, 2001), layanan publik diharuskan menerapkan unsur-unsur dasar antara lain:(1). Hak dan kewajiban baik penerima maupun pemberi layanan publik diharuskan jelas dan yang diketahui secara pasti masing-masing pihak. (2). Bentuk pelayanan yang diberikan disesuaikan dengan kondisi kebutuhan dan kemampuan masyarakat berdasarkan ketentuan perundang-undangan. (3). Kualitas, proses dan hasil pelayanan harus diupayakan agar dapat memberi keamanan, kenyamanan, kepastian hukum yang dapat dipertanggungjawabkan; dan (4). Apabila pelayanan dari pemerintah mahal, maka instansi pemerintah berkewajiban memberi peluang kepada masyarakat ikut serta melaksanakan sebagai penyelenggara.

Berkaitan dengan pelayanan publik yang profesional sesuai dengan tuntutan publik, menurut Thoha (Widodo, 2001) dalam Tesis (Irsan, 2012). Pelayanan publik profesional dapat diartikan sebagai pelayanan umum mempunyai karakterk akuntabilitas dan responsibilitas dari pemerintah, dengan ciri antara lain: (a). Efektif, mengutamakan pencapaian tujuan dan sasaran; (b). Sederhana, tata cara pelayanan diselenggarakan dengan mudah, cepat, tepat, tidak berbelit-belit, mudah dipahami oleh masyarakat; (c) Jelas dan transparan, artinya terdapat kejelasan dan kepastian mengenai; prosedur pelayanan, persyaratan pelayanan, unit kerja yang berwenang, biaya cara pembayarannya, waktu penyelesaian pelayanan. (d). Keterbukaan, yakni tata cara persyaratan satuan pejabat penanggungjawab pemberi pelayanan secara terbuka dan dipahami oleh masyarakat; (e). Efisiensi, yaitu persyaratan pelayanan hanya dibatasi pada hal-hal berkaitan langsung dengan pencapaian sasaran pelayanan dan dicegah adanya pengulangan pemenuhan persyaratan. (f). Ketepatan, ialah pelayanan diselesaikan dalam kurun waktu yang ditentukan. (g). Responsif, daya tanggap dan cepat yang dilayani, dan (h). Adaptif, menyelesaikan apa yang menjadi tuntutan, keinginan dan aspirasi masyarakat. Sedangkan menurut UU. No 25 Tahun 2009 menyebutkan bahwa pelayanan publik adalah susatu kegiatan dalam rangka memenuhi kebutuhan setiap warga yang sesuai dengan perundang-undangan atas brang, jasa dan/atau playanan administratif. Selain itu, standar pelayanan sekurang-kurangnya meliputi: (1). Kemudahan dalam prosedur pelayanan dan persyaratannya. (2). Waktu penyelesaian pelayanan dengan ketetapan. (3). Biaya pelayanan ditetapkan dalam proses pemberian pelayanan. (4). Produk pelayanan diterima sesuai ketentuan yang ditetapkan. (5). Sarana dan prasarana pelayanan memadai. (6). Kompetensi petugas pelayanan seperti pengetahuan, keahlian, keterampilan, sikap harus tepat.

Pada saat ini pelayanan yang disediakan oleh lembaga instansi yang ada di Indonesia masih banyak yang belum memberikan pelayanan yang maksimal. Dikutip dari mediaindonesia.com OMBUDSMAN Republik Indonesia (ORI) mengungkapkan bahwa saat ini tingkat kualitas pelayanan publik pemerintah semakin rendah. Selain itu, di Indonesia masih banyak ditemukan masalah- masalah dan hambatan yang terjadi di dalam pelayanan (Suryadi, 2010). Oleh karena itu, sistem pelayanan publik pada pemerintahan harus ditingkatkan lagi. Pemerintah daerah diharuskan berupaya untuk dapat melakukan pelayanan publik yang maksimal, berkualitas secara terus menerus. Namun, pernyataan tersebut masih belum berjalan dengan efektif, sesuai hasil kutipan dari ombudsman.com 
dalam TEMPO.CO, Jakarta Selasa, 30 Juli 2019 - Anggota Ombudsman, Ninik Rahayu, mengatakan bahwa pemerintah daerah merupakan instansi yang paling banyak dilaporkan masyarakat terkait pelayanan publik. Tidak terkecuali di Pemerintah Kota Jambi, banyaknya keluhan pelayanan publik yang diberitakan media massa.

Pemerintah Kota Jambi saat ini terus melakukan perbaikan terkait dalam pelayanan masyarakat baik secara konvensional maupun elektronik (E-Service Quality). E-ServQual adalah suatu kemampuan organisasi atau pemerintah dalam memenuhi apa yang dibutuhkan oleh masyarakat dengan menggunakan fasilitas internet. Menurut (Parasuraman,et al, 2005) menyatakan bahwa adanya E- ServQual ini menjadi sebagai isu strategis masa kini yang didorong oleh beranggapan bahwa E-ServQual merupakan suatu keunggulan yang kompetitif dan salah faktor keberhasilan bagi organisasi atau pemerintahan jangka panjang perusahaan. Kemudian menurut (Zeithaml,et al, 2002), EServQual adalah suatu kualitas layanan elektronik (E-ServQual) yang dipertimbangkan sejauh mana situs jaringan atau website yang memfasilitasi suatu kegiatan organisasi atau pelayanan bagi publik secara efektif dan efisien. Selain itu, menurut Boyer,et al. dalam Sousa,et al. (2006) menyatakan bahwa suatu pelayanan interaktif yang disampaikan melalui internet yang menggunakan teknologi multimedia, informasi dan telekomunikasi yang canggih. Sesuai pendapat dari Ponirin (2011) menyatakan bahwa E-ServQual adalah suatu evaluasi dan penilaian secara keseluruhan publik mengenai kualitas dari penyampaian layanan secara elektronik tersebut dalam ruang lingkup di pasar maya. Ada 5 komponen yang harus diperhatikan dalam e-servqual menurut Zeithaml et. Al dalam (Hongxiu Li, 2009) meliputi; (1) Security, eamanan data diri dan transaksi yang dirasakan dalam menggunakan aplikasi pelayanan organisasi, (2) Communication, kelancaran komunikasi antara organisasi dengan publik melalui aplikasi yang disediakan, (3) Reliability, kebenaran dan ketepatan informasi yang diberikan pihak organisasi melalui aplikasi. (4) Responsiveness, kecepatan dalam pelayanan dan tanggapan melalui media elektronik atau aplikasi yang diberikan oleh organisasi, dan (5) Delivery, tata cara dalam menyampaikan informasi dari organsisasi kepada publik seperti keramahan dan kesopan. Jika dikaitkan dengan pelayanan dapat jelaskan bahwa pengertian mengenai kualitas pelayanan seringkali diungkapkan para pelaku bisnis terdapat dalam buku kualitas pelayanan (Barata 2003): bahwa layanan prima antara lain, membuat masyarakat merasa penting, melayani masyarakat dengan ramah, tepat, dan cepat, pelayanan dengan mengutamakan kepuasan masyarakat, pelayanan optimal yang menghasilkan kepuasan masyarakat, menempatkan masyarakat sebagai mitra, keperdulian kepada masyarakat untuk memberikan rasa puas dan upaya layanan terpadu untuk kepuasan masyarakat.

Wali Kota Jambi Bapak Syarif Fasha mengatakan bahwa Kota Jambi berencana akan membangun layaknya mall atau graha khusus untuk pelayanan publik bagi masyarakat Kota Jambi. Tentu dengan adanya graha pelayanan tersebut akan memudahkan masyarakat Kota Jambi dalam mengurus administrasi atau pelayanan lainnya. Dikutip dari jambiindependent.co.id bahwa Pemerintah Kota Jambi telah menyediakan 14 aplikasi smart city pelayanan publik yang dapat di akses oleh masyarakat dengan terintegrasi online, antara lain: Digitalisasi Arsip Kepegawaian, Info Tagihan PBB Online, E-agenda, Perizinan Online, PPDB Online, Informasi Data ASN, Aplikasi Kliping Digital, Aplikasi PPID (Permohonan Informasi Publik), Aplikasi Dataset (Data Sekretariat), Dishub Sign On, Dishub Smart, Si Raja Koja (Sistem Informasi Pengadaan Barang Jasa Pemerintahan Kota Jambi), Si Kesal (Sistem Informasi Keluhan Masyarakat Online). Pemerintah Kota Jambi saat ini terus melakukan perbaikan terkait dalam pelayanan masyarakat baik dengan konvensional maupun elektronik (E-service Quality). 
Berdasarkan uraian diatas dapat dikatakan bahwa keseluruhan dari aplikasi tersebut tentu memiliki fungsi masing-masing. Pemerintah Kota Jambi berharap nantinya dapat membantu berbagai keluhan dari masyarkat Kota Jambi dalam perihal permasalahan yang akan dihadapi dari jarak jauh karena selama ini masyarakat yang terkesan enggan datang langsung ke kantor-kantor pelayanan publik, karena dengan adanya kualitas pelayanan publik yang maksimal sehingga masyarakat akan merasa puas. Selain itu adanya penyediaan layanan publik dapat membantu tata kelola pemerintahan yang nantinya akan dapat meningkatkan pelayanan kepada masyarakat (Chairudin dkk, 2017) menyatakan bahwa penyediaan pelayanan memang harus diprioritaskan sehingga dapat membantu kinerja pada aspek pelayanan untuk meningkatkan pelayanan kepada masyarakat.

Informasi yang diperoleh dari website resmi Pemerintah Kota Jambi jambikota.go.id bahwa Pemerintah Kota Jambi meraih penghargaan yang bergengsi di tingkat Nasional yakni di Indonesia's Attractiveness Award (IAA) selama 3 tahun berturut-turut. Pada tahun 2019 ini, Pemerintah Kota Jambi menyandang titel sebagai Kota Sedang Terbaik Sektor Pelayanan Publik dengan Peringkat Platinum. Sebagai masyarakat Kota Jambi tentu ini Prestasi yang sangat membanggakan, sejalan dengan itu prestasi tersebut tidak hanya sebagai simbol saja namun diharapkan mampu melayani masyarakat dan mampu mengatasi permasalahan yang diharapi masyarkat yang pada akhirnya terwujudnya kepuasan masyarakat tercapai. Sesuai dengan hasil penelitian (Bashir dkk, 2012) menyatakan bahwa adanya pengaruh yang signifikan kualitas pelayanan terhadap kepuasan masyarakat. Selain itu, hasil penelitian dari (Putra dkk, 2015) dan (rezha dkk, 2015) bahwa ada pengaruh secara signifikan atas kualitas pelayanan yang berikan pemerintah terhadap kepuasan yang terima oleh masyarkat. Dikutip oleh (Fandy Tjiptono, 2015) dalam Westbrook \& Reily bahwa kepuasan masyarakat sbagai berikut : "kepuasan masyarakat adalah respon emosional terhadap pengalaman- pengalaman berkaitan dengan produk atau jasa tertentu yang dibeli, gerai ritel, atau bahkan pola perilaku (seperti perilaku belanja dan perilaku pembeli), serta pasar secara keseluruhan. Respon emosional dipicu oleh proses evakuasi kognitif yang membandingkan persepsi (atau keyakinan) terhadap obyek, tindakan atau kondisi tertentu dengan nilai-nilai (atau kebutuhan, keinginan dan hasrat) individual". Selain itu, Daryanto dan Setyobudi (2014) kepuasan masyarakat meruapakan penilaian emosional dari masyarakat setelah masyarakat tersebut menggunakan produk ketika masyarakat merasa harapan dan kebutuhannya terpenuhi. Selain itu, menurut pendapat Selnes dalam (Endah, 2008), menyatakan bahwa kepuasan masyarakat adalah tingkat kepuasan secara keseluruhan, kesesuaian pelayanan sesuai dengan harapan masyarakat, dan tingkat kepuasan masyarakat selama menjalin hubungan dengan instansi atau organisasi. Sedangkan menurut Kepmen PAN No, 25 Th. 2004 bahwa kepuasan masyarakat adalah suatu pendapat masyarakat dlam memperoleh pelayanan dari penyelenggara pelayanan publik denga membandingkan antara harapan dan kebutuhannya. Dapat dikatakan bahwa kepuasan masyarakat merupakan tingkat perasaan seorang ketika menerima sesuatu yang ditawarkan dengan membandingkan kinerja atas sesuatu yang diterima dengan harapan yang dimiliki. Kemudian berdasarkan Permen PAN No 14 Tahun 2017, indikator-indikator kepuasan masyarakat sekurang-kurangnya antara lain: (1). Prosedur pelayanan, tata cara dalam pelayanan yang ditetapkan baik bagi pemberi maupun penerima pelayanan, termasuk selama proses pengaduan, kritik dan saran. (2). Waktu pelayanan, jangka waktu yang diperlukan untuk menyelesaikan pelayanan yang diajukan oleh masyarakat oleh pemerintahan. (3). Biaya pelayanan, berkaitan dengan biaya layanan selama dalam mengurus dan/atau memperoleh pelayanan dari pemerintahan. (4). Produk pelayanan, masyarakat atau publik menerima hasil 
pelayanan yang sesuai dengan yang telah dtetapkan pemerintah. (5). Kompetensi pelaksana, kemampuan dimiliki pegawai antara lain; pengetahuan, keahlian, keterampilan, dan pengalaman, dan (6). Sarana dan prasana, sarana adalah segala sesuatu yang digunakan sebagai alat dan penunjang dalam pelayanan kepada masyarakat.

\section{METODE}

Jenis dalam penelitian ini menggunakan penelitian deskriptif kuantitatif. Selain itu, penelitian ini juga melakukan pengumpulan data untuk melakukan uji hipotesis atau guna menjawab pertanyaan berhubungan variabel yang akan diteliti. Kemudian sumber data dalam penelitian ini terdiri data primer dan sekunder. Data premier yakni data diperoleh langsung dari responden dengan melalui kuesioner yang disebar. Sedangkan data sekunder ialah data diperoleh secara tidak langsung, data sekunder ini yang diperoleh dari seperti buku literatur, jurnal ilmiah dan internet. Kemudian penelitian ini menggunakan teknik pengumpulan data metode kuesioner yang diberikan kepada responden yang isinya berupa pernyataan tertulis berhubungan dengan objek penelitian yaitu pelayanan publik, e-service quality dan kepuasan masyarakat

Populasi yang diteliti dalam penelitian ini adalah masyarakat yang berada di Kota Jambi. Jumlah sampel pada penelitian ini adalah 60 orang. Penelitian ini mengunakan teknik purposive sampling. Purposive sampling yaitu teknik penentuan sampel dengan pertimbangan-pertimbangan yang memenuhi kriteria. Adapun kriteria tersebut adalah masyarakat yang memiliki NIK (Nomor Induk Kependudukan) di Kota Jambi dan sudah mendownload dan menggunakan aplikasi layanan berbasis internet yang sediakan oleh Pemerintahan Kota Jambi. Pengukuran variabel menggunakan skala Likert. Setiap pilihan jawaban responden diberi skor nilai yang disusun secara bertingkat berdasarkan Skala Likert tersusun sebagai berikut: Sangat setuju (5), setuju (4), Netral (3), tidak setuju (2) dan sangat tidak setuju (1)

Teknik Pengujian Instrumen Uji Validitas dan Uji Reliabilitas. Hasil uji ini valid jiks terjadi kesamaan antara data yg terkumpul dengan data yang sesungguhnya terjadi pada objek yang diteliti. Valid berarti instrument tersebut bisa digunakan dalam mengukur apa yang harus diukur. Sedangkan Reliabilitas merupakan sebagai pengukur untuk mengetahui seberapa tingginya instrument yang dipercayakan atau yang dapat diandalkan, atau bisa dikatakan bahwa reliabilitas menyangkut ketepatan alat ukur. Kemudian teknk analisis data dalam penelitian ini data akan dianalisa dan diolah berdasarkan bantuan aplikasi SPSS 21. Terdiri dari uji asumsi klasik uji normalitas, uji heteroskedastisitas, uji multikolinearitas, analisi regresi linieritas berganda, koefisien determinasi berganda, uji $\mathrm{F}$ secara bersama-sama dan uji t secara parsial.

\section{HASIL DAN PEMBAHASAN}

Dalam penelitian ini dilakukan uji validitas dan reliabilitas. Uji validitas sebagai mengukur apakah valid atau tidaknya indikator kuesioner penelitian, dapat dikatakan valid jika pernyataan kuesioner mampu mengungkapkan sesuatu yang diukur oleh kuesioner tersebut. Derajat kepercayaan pada uji signifikansi adalah 95\% $(\alpha=5 \%)$ dan nilai $r$ hitung akan dibanding dengan nilai $r$ tabel untuk nilai df (degree of freedom) $=n-2$. Jumlah sampel dalam penelitian ini berjumlah 60 orang, maka nilai df $=60-2=58$. Pada nilai Correlated Item-Total Correlation dengan hasil perhitungan nilai $r$ tabel $=0,211$. Apabila $\mathrm{r}$ hitung lebih besa dari $\mathrm{r}$ tabel dan nilai positif, maka item indikator tersebut dinyatakan valid. Pada penelitian ini menyatakan bahwa keseluruhan indikator yang digunakan untuk mengukur semua variabel yang digunakan dalam penelitian ini mempunyai koefisien korelasi yang lebih besar dari nilai $r$ table $=0,211$ (nilai $r$ table untuk $n=58$ ). Sehingga 
seluruh indikator tersebut adalah valid. Selanjutnya uji realibilitas pada pengujian ini menggunakan Cronbach Alpha $(\alpha)$, dimana apabila > 0,60 maka kuesioner dikatakan kosisten atau reliable. Reliabilitas merupakan untuk mengukur yang menunjukkan seberapa tingginya suatu instrument yang dapat dipercaya atau yang apat diandalkan, alat ukur yang digunakan adalah program SPSS versi 21 yang hasilnya disajikan pada tabel dibawah ini:

Tabel 1 Nilai Croncach's Variabel

\begin{tabular}{l|l|l}
\hline \multicolumn{1}{c|}{ Variabel } & \multicolumn{1}{c|}{ Croncach's } & \multicolumn{1}{c}{ Keterangan } \\
\hline Pelayanan Publik & 0.721 & Reliable \\
\hline E-service Quality & 0.789 & Reliable \\
\hline Kepuasan Masyarakat & 0.838 & Reliable \\
\hline
\end{tabular}

Sumber: Olah data SPSS (2020)

Hasil dari uji reliabilitas dalam tabel diatas dapat dikatakan bahwa keseluruhan variabel dalam penelitian ini mempunyai koefisien Alpha yang besar, yaitu > 0,60 maka dapat dikatakan bahwa kuesioner ialah sah atau semua pernyataan dalam kuesioner tersebut dapat menunjukkan apa yang telah diukur oleh kuesioner, dan dapat dikatakan handal dikarenakan semua jawaban dianggap konsisten dari waktu ke waktu. Selain itu, semua item pada setiap konsep variabel tersebut dapat dikatakan layak digunakan sebagai alat ukur. Kemudian untuk uji normalitas digunakan untuk mengetahui apakah nilai residual terdistribusi normal atau tidak. Guna mendeteksi apakah model regresi yang akan di analisis normalit atau tidak menggunakan analisis grafik Normal Probability Plot. Apabila histogram residual menunjukkan grafik distribusi normal maka dikatakan residual memiliki residual normal. Uji normalitas ini dilakukan menggunakan grafik Probability Plot. Data dapat dikatakan normal grafik terdapat bentuk titik-titik yang menyebar yang tidak jauh dari garis diagonal. Deteksi normalitas pada penelitian ini dapat dilihat melalui analisis grafik dengan grafik Normal Probability Plot dibawah ini:

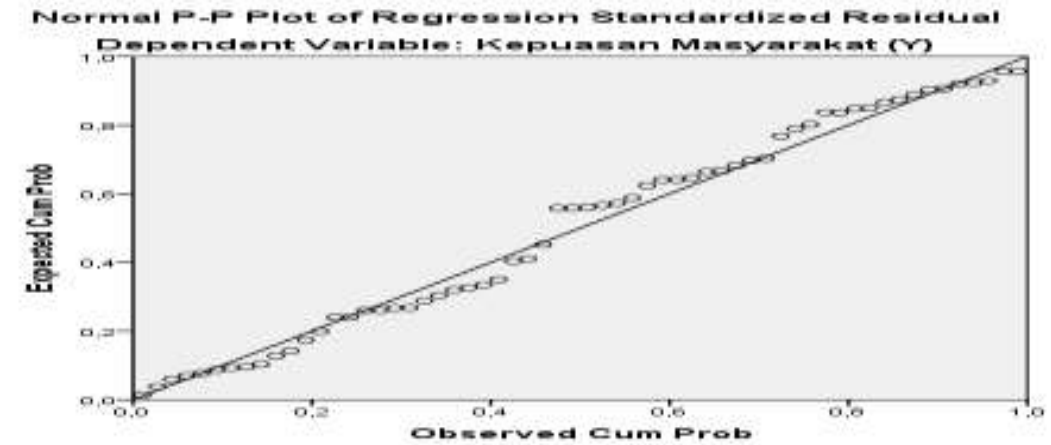

Gambar 2 Grafik Probability Plot

Di dalam uji heteroskedastisitas yang dinilai adalah ada ketidaknya kesamaan varian dari residual untuk semua pengamatan pada model regresi linear. Uji ini dapat dikatahui apabila pada grafik scatter plots tersebut terjadi pola tertentu, seperti titik-titik yang ada seperti membentuk pola tertentu yang sangat teratur (seperti bergelombang, melebar, atau menyempit), maka mengindikasikan telah terjadi Heteroskedastisitas dan sebaliknya apabila titik-titik yang menyebar diatas dan dibawah angka 0 pada sumbu Y tidak terjadi ada pola yang jelas atau, maka tidak terjadi Heteroskedastisitas. Dapat dilihat pada gambar dibawah ini: 


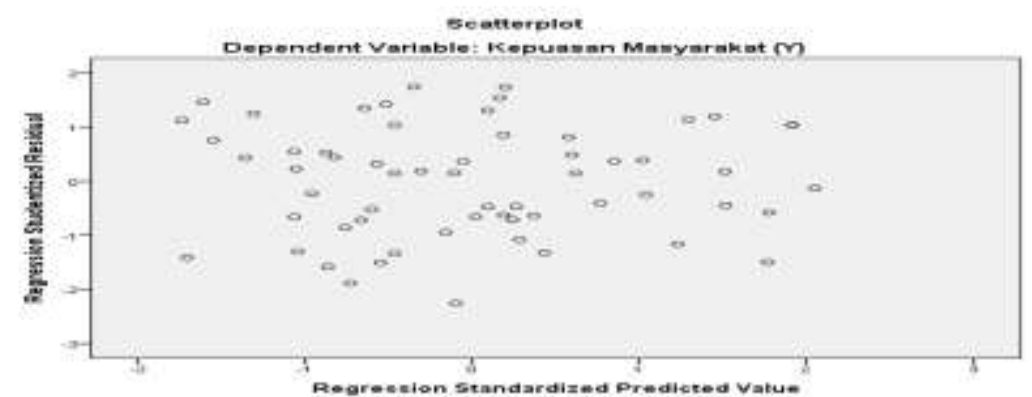

Gambar 3 Grafik ScatterPlots

Selain itu, uji multikoliearitas bertujuan untuk mengetahui ada tidaknya korelasi atau hubungan yang tinggi antara semua variabel bebas, maka dapat dilihat dari nilai Tolerance dan VIF (Varians Inflation Factor). Jika terjadi korelasi maka terjadi adanya masalah multikolienaritas. Seharusnya model yang baik tidak terjadinya korelasi atau hubungan antara variabel. Dapat diketahui dari nilai VIF dan Tolerance.

Tabel 2 Angka VIF dan Tolerance

\begin{tabular}{l|l|l}
\hline Model Constant & Collinearity Statistics & \\
\hline & Tolerance & VIP \\
\hline Pelayanan Publik & 0.708 & 1.412 \\
E-Service Quality & 0.708 & 1.412 \\
\hline
\end{tabular}

Sumber: Olah data SPSS (2020)

Selanjutnya analisis regresi linieritas berganda untuk mengetahui arah hubungan antara variabel bebas dengan variabel terikat, apakah variabel bebas berhubungan bernilai negatif atau pun positif serta memprediksi nilai variabel terikat apabila nilai variabel bebas mengalami kenaikan atau penurunan.

Tabel 3 Hasil regresi linieritas berganda

\begin{tabular}{l|l|l}
\hline Model Constant & Unstandardized Coefficients & \\
\hline & $\mathrm{B}$ & Std.Error \\
\hline Pelayanan Publik & -4.924 & 2.780 \\
E-Service Quality & 0.815 & 0.097 \\
& 0.290 & 0.091 \\
\hline
\end{tabular}

Sumber: Olah data SPSS (2020)

Hasil pada tabel diatas dapat diketahui pengaruh pelayanan publik terhadap kepuasan masyarakat, dapat dikatakan bahwa variabel $\mathrm{X}_{1}$ yakni pelayanan publik memberikan pengaruh positif terhadap variabel $\mathrm{Y}$ yakni kepuasan masyarakat. Peningkatan pelayanan publik $\left(\mathrm{X}_{1}\right) 1$ satuan akan meningkatkan kepuasan masyarakat $(\mathrm{Y})$ sebesar 0.815 . Kemudian pengaruh variabel $\mathrm{X}_{2}$ yakni E-service quality terhadap variabel kepuasan masyarakat (Y), selain itu, dapat diketahui bahwa Variabel E-service quality $\left(\mathrm{X}_{2}\right)$ memberikan pengaruh positif terhadap kepuasan masyarakat $(\mathrm{Y})$. Peningkatan Eservice quality $\left(\mathrm{X}_{2}\right)$ sebesar 1 satuan akan meningkatkan variabel kepuasan masyarakat (Y) sebesar 0, 290. Maka dapat dibuat persamaan regresi linear yang mencerminkan hubungan antara variabel-variabel dalam penelitian ini yang berdasarkan tabel diatas adalah sebagai berikut:

$$
Y=-4.924+0,815 X 1+0,290 X 2
$$

Keterangan: $\mathrm{X}_{1}=$ Pelayanan Publik, $\mathrm{X}_{2}=\mathrm{E}$-Service Quality, $\mathrm{Y}=$ Kepuasan Masyarakat

Uji koefisien determinasi dapat digunakan mengetahui nilai persen dari perubahan variabel independen yang dapat menjelaskan perubahan yang terjadai pada variabel 
dependen. Koefisien determinasi berganda bertujuan untuk mengetahui seberapa besar sumbangan atas pengaruh dari variabel independen secara bersama terhadap variabel dependen. Kemudian sisanya dipengaruhi oleh variabel-variabel lain yang tidak dimasukkan ke dalam penelitian

Tabel 4 Angka R Square

\begin{tabular}{l|l|l}
\hline Model & R & R Square \\
\hline 1 & .856 & .732 \\
\hline
\end{tabular}

Sumber: Olah data SPSS (2020)

Dari tabel di atas dapat diketahui nilai sebesar $\mathrm{R} 2=0,723$ atau $72,3 \%$ variasi variabel dependen (variabel Y) dapat dijelaskan oleh variabel independen (Varibel $\mathrm{X}_{1}$ dan $\mathrm{X}_{2}$ ). Selain itu, sisanya sebesar $27,7 \%$ yang dijelaskan variabel di luar model ini.

Tujuan dari uji $\mathrm{F}$ adalah untuk mengetahui nilai dari pengaruh variabel independen terhadap variabel dependen secara bersamaan. Untuk mengetahui signifikan $\mathrm{F}$ hitung apakah lebih besar dari alpha yang ditetapkan $(0,05)$ atau tidak pada tabel dibawah ini:

Tabel 5 Angka F -hitung

\begin{tabular}{l|l|l|l}
\hline Model & df & F & Sig. \\
\hline Regression & 2 & 77.974 & $.000^{\mathrm{b}}$ \\
\hline Residual & 57 & & \\
\hline Total & 59 & & \\
\hline
\end{tabular}

Sumber: Olah data SPSS (2020)

Dari tabel diatas dapat diketahui nilai $\mathrm{F}$ hitung $=77,974$ dengan signifikansinya $=$ 0,000. Dikarenakan nilai F hitung > F- tabel $(3,16)$ dan signifikansi lebih kecil dari 0,05 maka model regresi dapat digunakn memprediksi variabel dependen, atau dapat dkatakan variabel pelayanan publik $\left(\mathrm{X}_{1}\right)$ dan e-service quality $\left(\mathrm{X}_{2}\right)$ berpengaruh secara positif dan signifikan terhadap variabel kepuasan masyarakat (Y). Kemudian untuk Uji t bertujuan mengetahui niali pengaruh setiap variabel independen secara parsial terhadap variabel dependen. Uji $\mathrm{t}$ dilakukan mengetahui signifikansi $\mathrm{t}$ hitung yang diperoleh dari pembanding dengan alpha yang ditetapkan $(0,05)$ dan juga membandingkan $t$ hitung terhadap t tabel $=2,00$.

Tabel 6 Angka t -hitung

\begin{tabular}{l|l|l}
\hline Model & $\mathrm{t}$ & Sig. \\
\hline Constant & -1.771 & .082 \\
Pelayanan publik & 8.425 & .000 \\
E-service quality & 3.209 & .002 \\
\hline
\end{tabular}

Sumber: Olah data SPSS (2020)

Pada tabel diatas menunjukkan hasil uji $\mathrm{t}$ variabel $\mathrm{X}_{1}$ menunjukkan signifikan sebesar 0,000 , nilainya lebih kecil dari alpha $(0,05)$ dan t hitung $(8.425)$ lebih besar dari pada t tabel $(2,00)$, sehingga tolak $\mathrm{H} 0$ dan terima $\mathrm{H} 1$ yang berarti Variabel $\mathrm{X}_{1}$ berpengaruh signifikan terhadap Variabel $\mathrm{Y}$. Kemudian uji $\mathrm{t}$ variabel $\mathrm{X}_{2}$ menunjukkan signifikan sebesar 0,002, nilainya lebih kecil dari alpha dan nilai thitung (3.209) lebih besar daripada nilai t tabel $(2,00)$, sehingga tolak $\mathrm{H} 0$ dan terima $\mathrm{H} 1$ yang berarti variabel $\mathrm{X}_{2}$ berpengaruh signifikan terhadap variabel Y. Selain itu, uji signifikansi t dilihat dari nilai probabilitas (Sig) dibandingkan dengan nilai tingkat signifikansi $\alpha=0,05$. Bila prob $<\alpha$, maka variabel tersebut signifikan. Berdasarkan hasil uji signifikansi diperoleh variabel $X_{1}$ dan $X_{2}$ 
signifikan mempengaruhi variabel $\mathrm{Y}$.

Di dalam penelitian ini untuk meningkatkan kepuasan masyarakat faktor yang sangat dipertimbangkan dalam pelayanan publik antara lain; (1) kemudahan dalam prosedur pelayanan dan persyaratannya, (2) aktu penyelesaian pelayanan dengan ketetapan, (3) biaya pelayanan ditetapkan dalam proses pemberian pelayanan, (4) produk pelayanan diterima sesuai ketentuan yang ditetapkan, (5) sarana dan prasarana pelayanan memadai, (6) kompetensi petugas pelayanan seperti pengetahuan, keahlian, keterampilan, sikap harus tepat. Di dalam penelitian ini terdapat pengaruh yang positif pelayanan publik terhadap kepuasan masyarakat. Maka hasil penelitian ini sejalan dengan penelitian yang dilakukan oleh Chairudin dkk (2017) yang berjudul high performance is not always directly proportional to service quality: a case of one-stop service of Sragen dengan hasil penelitiannya bahwa penyediaan pelayanan publik memang harus diprioritaskan sehingga dapat membantu kinerja pada aspek pelayanan untuk meningkatkan pelayanan kepada masyarakat. Selain itu, sejalan penelitian yang dilakukan oleh Bashir dkk (2012) dengan judul: the effect of service quality and government role on custumer satisfaction empirical evidence of Microfinance in Kenya, bahwa hasil penelitiannya adalah the findings of this study show that the effect of service quality on customer satisfaction is positive and significant artinya penelitian ini menunjukkan bahwa kualitas layanan berpengaruh positif terhadap kepuasan palanggan (kepuasan masyarakat).

E-Service Qualility adalah suatu kualitas layanan elektronik (E-ServQual) yang dipertimbangkan sejauh mana situs jaringan atau website yang memfasilitasi suatu kegiatan organisasi atau pelayanan bagi publik secara efektif dan efisien. Fakktor yang pertimbangkan dalam meningkatkan kepuasan masyarakat antra lain: 1) Security. Keamanan data diri dan transaksi yang dirasakan dalam menggunakan aplikasi pelayanan organisasi. 2) Communication. Kelancaran komunikasi antara organisasi dengan publik melalui aplikasi yang disediakan. 3) Reliability. Kebenaran dan ketepatan informasi yang diberikan pihak organisasi melalui aplikasi. 4) Responsiveness. Kecepatan dalam pelayanan dan tanggapan melalui media elektronik atau aplikasi yang diberikan oleh organisasi. 5) Delivery. Tata cara dalam menyampaikan informasi dari organsisasi kepada publik seperti keramahan dan kesopan. Hasil penelitian ini sesuai dengn penelitian dari Engdaw (2019) yang berjudul the impact of quality public service delivery on customer satisfaction in Bahir Dar City Admnistraion: the case of Ginbot 20 Sub-city yang menyatakan bahwa kualitas pelayanan berpegaruh postif terhadap kepuasan masyarakat. Kemudian sejalan juga dengan hasil penelitian yang dilakukan oleh Putra dkk (2015) berjudul pengaruh kualitas pelayanan trhadap kepuasan masyarakat (studi pda dinas kepndudukan dan pncatatan sipil Kota Blitar) hasil penelitian adanya pengaruh secara signifikan kualitas pelayanan terhadap kepuasan masyarakat. Selain itu, penelitian ini juga sejalan dengan penelitian yang dilakuakan oleh Rezha dkk (2013) dengan judul penelitian analisis pengaruh kualitas pelayanan publik terhadap kepuasan masyarakat (studi tentang pelayanan perekaman Kartu Tanda Penduduk Elektronik (e-KTP) di Kota Depok dengan hasil penelitiannya kualitas pelayanan memiliki pengaruh yang positif terhadap kepuasan masyarakat Kota Depok

Sedangkan hasil pengaruh pelayanan publik dan e-service quality secara bersama terhadap kepuasan masyarakat di pemerintahan Kota Jambi. Artinya jika pelayanan publik dan e-service quality ditingkatkan secara bersama-sama, maka indikator-indikator kepuasan masyarakat akan terpenuhi. Indikator yang dimaksud (Permen PAN No 14 Tahun 2017) antara lain; 1. Prosedur pelayanan, tata cara dalam pelayanan yang ditetapkan baik bagi pemberi maupun penerima pelayanan, termasuk selama proses 
pengaduan, kritik dan saran. 2. Waktu pelayanan, jangka waktu yang diperlukan untuk menyelesaikan pelayanan yang diajukan oleh masyarakat oleh pemerintahan 3. Biaya pelayanan, berkaitan dengan biaya layanan selama dalam mengurus dan/atau memperoleh pelayanan dari pemerintahan 4. Produk pelayanan, masyarakat atau publik menerima hasil pelayanan yang sesuai dengan yang telah dtetapkan pemerintah. 5. Kompetensi pelaksana, kemampuan yang diharuskan dimiliki pegawai antara lain: pengetahuan, keahlian, keterampilan, dan pengalaman 6. Sarana dan prasana, sarana adalah segala sesuatu yang digunakan sebagai alat dan penunjang dalam pelayanan kepada masyarakat.

\section{SIMPULAN DAN SARAN}

\section{Simpulan}

1. Terdapat pengaruh positif yang signifikan pelayanan publik terhadap kepuasan masyarakat di pemerintah Kota Jambi

2. Terdapat pengaruh positif yang signifikan e-service quality terhadap kepuasan masyarakat di pemerintah Kota Jambi

3. Terdapat pengaruh positif yang signifikan pelayanan publik dan e-service quality terhadap kepuasan masyarakat secara bersama-sama di pemerintah Kota Jambi

\section{Saran}

Hendaknya pemimpin pemerintah Kota Jambi memperhatikan faktor-faktor yang dianggap mempengaruhi terhadap kepuasan masyarakat. Seperti memperhatikan dalam prosedur pelayanan terhadap masyarakat, memperbaiki tata cara dalam pelayanan, termasuk selama proses pengaduan, kritik dan saran dari masyarakat, selanjutnya memperhatikan waktu proses pelayanan yang dilakukan, dikarenakan efisiensi daam menyelesaikan permasalahan masyarakat juga turut dalam kenyamanan atau kepuasan yang dirasakan masyakarat. Selain itu, tentang biaya pelayanan perlu diperhatikan, ini berkaitan selama biaya pengurusan pelayanan.

Kemudian perihal produk pelayanan yang dihasilkan oleh pemerintah akan memberi dampak terhadap kepuasan yang dirasakan oleh masyarakat. Kompetensi petugas juga perlu ditingkatkan, bahkan keahlian, keterampilan dan pengalaman yang dimiliki petugas akan memberikan dampak positif terhadap pelayanan yang diberikan kepada masyarakat. Dan yang terakhir berkaitan dengan sarana dan prasarana, segala sesuatu yang digunakan sebagai alat dan penunjang dalam memberikan pelayanan kepada masyarakat di Kota Jambi

\section{DAFTAR PUSTAKA}

Bashir, M S. Machali, M M. Mwinyi A M. (2012). The Effect of Service Quality and Government Role on Customer Satsfaction: Emprical Evidence of Mcrofinance in Kenya. Intrnational Journal of Business and Social Science. Vol. 3 No. 14

Chairudin, moehhamad. Setyowati, K. Guharto, DG. (2017). High Performance is Not Always Directly Proportional to Service Quality: A Case of One-Stop Service of Sragen. International Journal of Administrative Science\&Organization.Vol. 24 No. 2

Engdaw B Dejen. (2019). the impact of quality public service delivery on customer satisfaction in Bahir Dar City Admnistraion: the case of Ginbot 20 Sub-city. International Journal of Public Administration. Vol 43. Page 644-645

Endah, Rayi. (2008). “Analisis Kualitas Layanan, Kualitas Produk, dan Harga Terhadap Kepuasan Pelanggan”. Skripsi, Universitas Diponegoro.

Hendriyaldi. (2019). Revolusi Industri 4.0: Tantangan dan Peluang Manajemen Sumber Daya Manusia Untuk Meningkatkan Produktivitas Grand Hotel Jambi. Jurnal 
Manajemen dan Sains. Vol. 4 No. 2

Hongxiu Li, Reima Soumi, Yong Liu. (2009). Measurement of e-sercle quality :an empirical study on online travel service. 17th European Confrence on information systems journal

Irsan. (2012). "Kualitas Pelayanan Kesehatan Pada Puskesmas Simpur di Bandar Lampung". Tesis. Universitas Lampung. Bandar Lampung

Klaus Schwab (2017), The Fourth Industrial Revolution, Publisher: Penguin; 1st Edition

Liffler, M., \& Tschiesner, A. (2013). The Internet of Things and the Future of Manufacturing. McKinsey \& Company.

Parasuraman, A. Dan Valerie A. Zeithaml dan Arvind Malhotra. (2005). E-S- QUAL, A Multiple-Item Scale for Assessing Electronic Service Quality. Journal of Service Research. Volume 7 No.X:1-21. Doi: 10.1177/1094670504271156. Sage Publication

Putra, D G. Pratiwi, R N. Trisnawati. (2015). Pengaruh kualitas pelayanan terhadap kepuasan masyarakat (Studi pada Dinas Kependudukan dan Pencatatan Sipil Kota Blitar). Jurnal Administrasi Publik (JAP), Vol. 3, No. 12

Priyantno, Duwi. (2010). Teknik Mudah dan Cepat Melakukan Analisis Data Penelitian Dengan SPSS dan Tanya Jawab Ujian Pendadaran. Yogyakarta: Gava Media.

Rezha, Fahmi. Rochmah, Siti, Siswidiyanto. (2015). Analiss pengaruh kualitas playanan publik terhadap kepuasan masyarakat (Studi tentang Pelayanan Perekaman Kartu Tanda Penduduk Elektronik (e-KTP) di Kota Depok). Jurnal Administrasi Publik (JAP), Vol 1, No.5

Santoso, Singgih. (2010). Statistik Parametrik, Konsep dan Aplikasi dengan SPSS. Cetakan Pertama, PT Elex Media Komputindo, Jakarta, PT Gramedia, Jakarta

Sousa, Rui and Christopher A. Voss, (2009) "The effects of service failures and recovery on customer loyalty in e-services: An empirical investigation", International Journal of Operations \& Production Management, Vol. 29 Issue: 8,: pp.834-864

Sugiyono. (2012). Metode Penelitian Kuantitatif Kualitatif dan R\&D. Bandung: Alfabeta

Sugiyono. (2007). Metode Penelitian Kuantitatif Kualitatif dan R\&D. Bandung: Alfabeta

Suryadi. (2010). Penanganan Keluhan Publik Pda Birokrasi Dinas Perijinan Kota Malang. Fakultas Ilmu Administrasi, UB, Jurnal Vol.23 No.4 hlm 293-303.

Zeithaml et al. (2002). Service Marketing : Integrating Customer Focus Across the Firm. United Stated of America : International Edition. Mc.Graw-Hill

KEPMEN PAN Nomor 25 Tahun 2004 tentang Pedoman Umum Penyusunan Indeks Kepuasan Masyarakat Unit Pelayanan Instansi Pemerintah

PERMEN PAN Nomor 14 Tahun 2017 tentang Pedoman Penyusunan Survei Kepuasan Masyarakat Unit Penyelenggara Pelayanan Publik

UNDANG UNDANG REPUBLIK INDONESIA Nomor 25 Tahun 2009 tentang Pelayanan Publik

https://mediaindonesia.com/read/detail/247783-ombudsman-ungkap-kualitas-pelayananpublik di akses pada tanggal 10 Februari 2020

https://ombudsman.go.id/news/r/ombudsman-pelayanan-pemda-paling-banyak-diadukanmasyarakat di akses pada tanggal 12 Februari 2020

https://metrojambi.com/read/2019/09/02/46809/pemkot-jambi-berencana-membangunmal-pelayanan-publik-- di akses pada tanggal 13 Februari 2020

https://jambi-independent.co.id/read/2017/12/15/16665/14-aplikasi-menuju-smart-city/ di akses pada tanggal 13 Februari 2020

https://jambikota.go.id/new/2019/07/24/hatrick-kota-jambi-kembali-raih-penghargaan-iaa/ di akses pada tanggal 16 Februari 2020. 